\title{
Pattern of Mobile Phone Use among Students of an Institution
}

\author{
Kriti Thapa, ${ }^{1}$ Rita Pokharel, ${ }^{1}$ Rambha Sigdel, ${ }^{2}$ Surya Prasad Rimal ${ }^{3}$ \\ 'Department of Psychiatric Nursing, B.P. Koirala Institute of Health Sciences, Dharan, Nepal, ${ }^{2}$ Department of Community \\ Health Nursing, B.P. Koirala Institute of Health Sciences, Dharan, Nepal, ${ }^{3}$ Department of Obstetrics and Gynecology, B.P.
} Koirala Institute of Health Sciences, Dharan, Nepal.

\section{ABSTRACT}

Introduction: The charm of mobile phone is more among young generation and the increasing use can lead to various harmful effects and may result in dependence. The objective of the study is to evaluate the pattern of mobile phone use among medical students.

Methods: A descriptive cross sectional study was conducted on a total of 229 medical students aged between 18 and 25 years who were using mobile phones for more than 1 year by using simple random sampling technique. Students were requested to complete a pre-tested self-administered questionnaire which comprised their socio-demographic characteristics and pattern of mobile phone usage.

Results: Among the total 229 students, all of them had their own smart phones. Major purpose of using mobile was for calling, listening music, taking photos/videos and internet use. Most of the students 97 (42.4\%) have owned mobile phones since $4-6$ years. The median time spent by the students on the mobile phone using different features of mobile phone was 3.5 hours. Majority of the students i.e. 157 (68.5\%) use mobile phones at night. The median amount of money spent on recharge per month was 500 . Age of student was significantly $(\mathrm{P}<0.05)$ associated with calls per day. There was no significant association of pattern of mobile phone use with other selected socio-demographic variables

Conclusions: Students were found to use mobile phone excessively. The pattern of mobile phone usage among the students in this study may signal the evolution of mobile phone use from a habit to an addiction.

Keywords: gender differences; medical students; mobile phone usage pattern.

\section{INTRODUCTION}

Mobile phone because of the ever availability and its mobility application has created a dramatic interest for youth in comparison with other communication technologies. ${ }^{1}$ Initially, mobile phones were used only as a communication tool but these days, mobile phones function as mobile computers that serve us with music player, games, internet, video camera, calculator, alarm clock, and many more other perceived benefits as increased accessibility and social connectivity, reduced loneliness, and security in emergency situations. ${ }^{2}$

Unfortunately, communication technology has some negative effects also. Constant usage and addiction to cell phones has affected the people physically, psychologically, and socially. ${ }^{3}$ Self-reported symptoms associated with using mobile phones most commonly included headaches, earache, warmth sensations, concentration difficulties and fatigue. ${ }^{4}$ Moreover,

Correspondence: Kriti Thapa, Department of Psychiatric Nursing, College of Nursing, B.P. Koirala Institute of Health Sciences, Dharan, Nepal. Email: thapakriti04@gmail.com, Phone: +977-9846083150. 
intensive mobile phone use has been associated with dependency on the mobile phone. ${ }^{5}$

The objective of the study is to evaluate the pattern of mobile phone use among students of a medical university of Eastern Nepal.

\section{METHODS}

A descriptive cross sectional study was conducted on a total of 229 students of a medical university of Eastern Nepal from October 2016 to December 2016. The study was approved by Institutional Review Committee of B.P. Koirala Institute of Health Sciences on 24th July, 2016. Written consent was taken from each participants and confidentiality was maintained. Students who were using mobile phones on a regular basis for more than 1 year were included by using simple random sampling technique. Students were requested to complete a pre-tested self-administered questionnaire which comprised their socio-demographic characteristics and pattern of mobile phone usage. The data were compiled and analyzed in SPSS version 16 and expressed as frequency and percentages. The data were analyzed statistically using $\chi^{2}$-test to observe the association between pattern of mobile phone use and selected socio-demographic variables.

\section{RESULTS}

Table 1 shows pattern of mobile phone use among the medical students. Table 2 depicts the association of pattern of mobile phone use with selected socio demographic variables. In this study, majority of the participants, i.e. $122(53.3 \%)$ were in the age group $22-25$ years with mean age of $21.73 \pm 1.6$ years. Of the total study population, most of them i.e. 97 $(42.4 \%)$ have owned mobile phones since 4-6 years (Median: 5.31 IQR (7 -3)). Table 3 shows demographic characteristics of the study population. Moreover, family income status was not associated significantly with money spent on recharge per month ( $P$ value $=0.437$ ).
Table 1. Pattern of mobile phone use.

\begin{tabular}{|c|c|c|}
\hline Characteristics & Category & n (\%) \\
\hline \multirow{5}{*}{$\begin{array}{l}\text { Time spent per } \\
\text { day }\end{array}$} & $1-2$ hours & $67(29.2)$ \\
\hline & $2-4$ hours & $82(35.8)$ \\
\hline & 4-6 hours & $42(18.3)$ \\
\hline & $>6$ hours & $38(16.5)$ \\
\hline & \multicolumn{2}{|c|}{ Median-3.5 IQR (5-2) } \\
\hline \multirow{4}{*}{ Calls per day } & $1-5$ & $142(62)$ \\
\hline & $6-10$ & $54(23.6)$ \\
\hline & $>10$ & $33(14.4)$ \\
\hline & \multicolumn{2}{|c|}{ Median - 4.5 IQR (8.25-2.5) } \\
\hline \multirow{5}{*}{ SMS per day } & 0 & $71(31.0)$ \\
\hline & $1-4$ & $110(48.0)$ \\
\hline & $5-8$ & $21(9.2)$ \\
\hline & $>8$ & $27(11.8)$ \\
\hline & \multicolumn{2}{|c|}{ Median- 1.5 IQR (3.5-0.0) } \\
\hline \multirow{5}{*}{$\begin{array}{l}\text { Money spent } \\
\text { on recharge per } \\
\text { month }\end{array}$} & $<$ Rs. 500 & $111(48.5)$ \\
\hline & $\begin{array}{l}\text { Rs. 500- } \\
1000\end{array}$ & $95(41.5)$ \\
\hline & >Rs. 1000 & $23(10.0)$ \\
\hline & Median: 500 & $(675-200)$ \\
\hline & Morning & $8(3.4)$ \\
\hline \multirow{4}{*}{$\begin{array}{l}\text { Time of } \\
\text { maximum use }\end{array}$} & Afternoon & $16(6.9)$ \\
\hline & Evening & $73(31.8)$ \\
\hline & Night & 157 (68.5) \\
\hline & Classroom & $13(5.6)$ \\
\hline \multirow{6}{*}{$\begin{array}{l}\text { Place/ Situation } \\
\text { of maximum use }\end{array}$} & Library & $5(2.1)$ \\
\hline & Eating & $7(3.05)$ \\
\hline & Driving & $1(0.43)$ \\
\hline & Room & $219(95.6)$ \\
\hline & $\begin{array}{l}\text { Calling } \\
\text { family } \\
\text { members }\end{array}$ & 209 (91.2) \\
\hline & $\begin{array}{l}\text { Calling } \\
\text { friends }\end{array}$ & $182(79.47)$ \\
\hline \multirow[t]{6}{*}{ Reason for use } & Messaging & $132(57.64)$ \\
\hline & Internet use & $216(94.32)$ \\
\hline & $\begin{array}{l}\text { Playing } \\
\text { games }\end{array}$ & $136(59.38)$ \\
\hline & $\begin{array}{l}\text { Listening to } \\
\text { music }\end{array}$ & $170(74.23)$ \\
\hline & $\begin{array}{l}\text { Taking } \\
\text { photos/ } \\
\text { videos }\end{array}$ & $160(69.86)$ \\
\hline & $\begin{array}{l}\text { Study } \\
\text { purpose }\end{array}$ & $33(14.41)$ \\
\hline
\end{tabular}

$(n=229)$ 
Thapa et al. Pattern of Mobile Phone Use among Students of an Institution

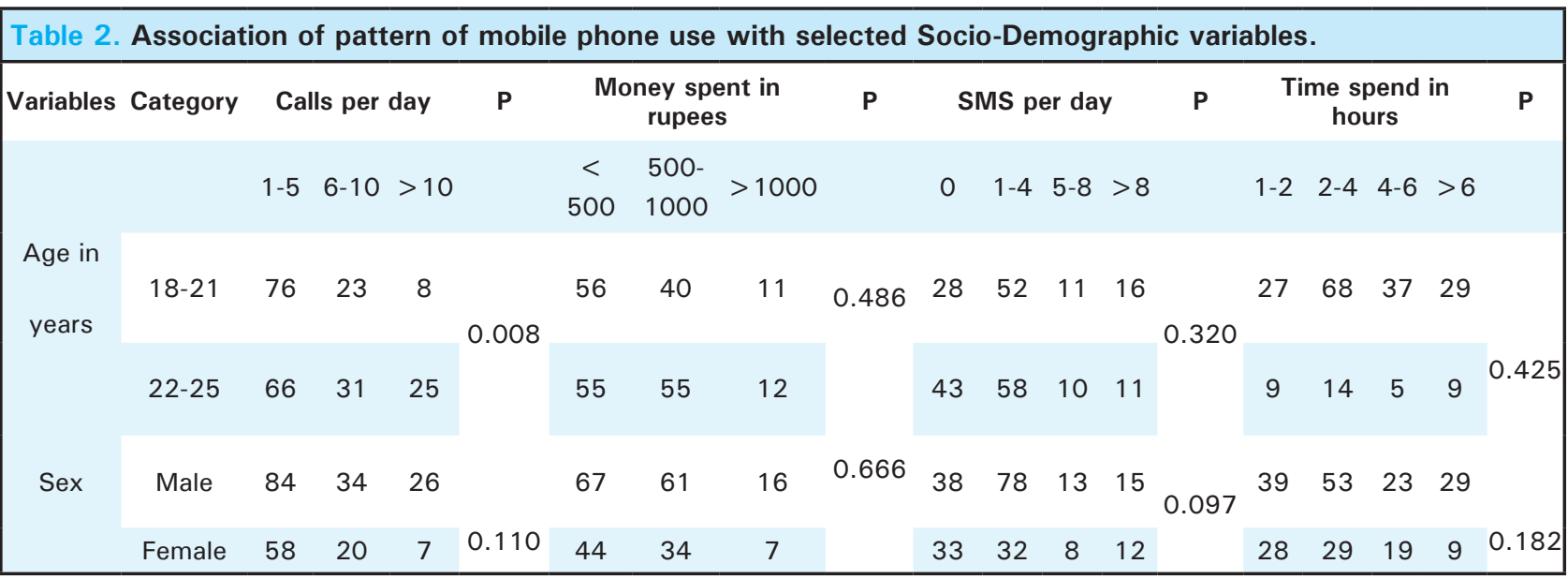

$(n=229)$

\begin{tabular}{|llc|}
\hline \multicolumn{3}{|l|}{$\begin{array}{l}\text { Table 3. Socio-Demographic variables of the } \\
\text { respondents. }\end{array}$} \\
\hline \multicolumn{1}{|c|}{ Characteristics } & \multicolumn{1}{l|}{ Category } & n (\%) \\
Sex & Male & $144(62.9)$ \\
& Female & $85(37.1)$ \\
Type of family & Joint & $37(16.2)$ \\
& Nuclear & $192(83.8)$ \\
Family income & Bad & $2(0.9)$ \\
status & Average & $145(63.3)$ \\
& Good & $82(35.8)$ \\
& $1^{\text {st }}$ year & $49(21.4)$ \\
Academic year & $2^{\text {nd }}$ year & $48(21.0)$ \\
& $3^{\text {rd }}$ year & $50(21.8)$ \\
& $4^{\text {th }}$ year & $46(20.1)$ \\
& $5^{\text {th }}$ year & $36(15.7)$ \\
\hline
\end{tabular}

$(n=229)$

\section{DISCUSSION}

Mobile phone use has pervaded into every aspect of the community and it has a special presence in the lives of young, college going students. However, its excessive use and its health effects are relatively new issues that have come forth only in the recent years. ${ }^{6}$

In this present study all of the students had their own smart mobile phone similar to findings in other studies. ${ }^{7,8}$

This study revealed that most of the students 97 (42.4\%) owned mobile phone since 4-6 years which is in contrast with study done among the youths in Mumbai. In this study only $14 \%$ of them were using mobile for $4-6$ years. $^{9}$

The median time spent by the students on the mobile phone using different features of mobile phone was 3.5 hours. In this study, it was found that mobile phone use was very high among the medical students of both sexes with $82(35.8 \%)$ of them spending $2-4$ hours per day on their mobile which is comparable to the study done in Dehradun, India and Dhaka, Bangladesh In those studies, $57 \%$ and $34.8 \%$ of the medical students were using mobile phones for more than 2 hours and more than 4 hours respectively. ${ }^{10,11}$ In contrast study done in Punjab showed that only $17.8 \%$ were spending more than 3 hours on their mobile. ${ }^{7}$ Moreover, 38 $(16.5 \%)$ of the students spent more than 6 hours on their mobile phone. The use of mobile for prolonged duration can lead to many harmful effects ${ }^{3}$ and may signal the evolution of mobile phone use from a habit to an addiction. ${ }^{12}$

Many of the students were calling 1-5 persons per day in the present study which is comparable to study done in a medical university in India. ${ }^{7}$

The number of students who sent more than 8 SMS in the present study was only $27(11.8 \%)$. Moreover, it was found that $71(31 \%)$ of the students did not use SMS which is in contrast with other studies. ${ }^{6,13,14}$ The most plausible explanation for that is SMS feature is expensive compared to calls in our country.

Most of the students were frequently using mobile phone for taking pictures/ videos, playing games, listening to music and internet surfing other than for calling and messaging purpose as was found in other studies. ${ }^{7,15}$ In this study it was found that 209 (91.2\%) of the students used mobile phone for calling their family members which is similar to many other studies. ${ }^{6,16}$ The reason for this could be that large proportion of the students in this institution are from other parts of the country and also from India and that they found it easier to keep in contact with their parents through mobile phones.

Majority of the students used mobile phones at night 
Thapa et al. Pattern of Mobile Phone Use among Students of an Institution

$157(68.5 \%)$ and around $73(32 \%)$ of them used in the evening which is similar to study done in South India ${ }^{6}$ which may be due to the busy schedule in the morning and afternoon. However, late hours and extended use of mobile phone for communication may cause emotionally and cognitive arousal in pre sleep period that leads to poor quality of sleep and insomnia. ${ }^{10}$

The median amount of money spent on recharge per month was 500 which is comparable to other studies done in India. ${ }^{73}$ Moreover, this amount was found to be much less than spent by Malaysian students in another study. This difference could be due to the fact that Nepalease students try to keep check on their expenditure.

In this study $13(5.6 \%)$ of the students were found to be using mobile phones in class room. A study carried out in a medical university of India found that $18 \%$ of the students used mobile phone in the class. ${ }^{7}$

Only $1(0.43 \%)$ of them had the habit of using mobile during driving which is in contrast with the study done among youths in Mumbai $^{9}$ which shows $10.84 \%$ of them used mobile phone while driving. Similarly, 31\% of the medical students in Kerala ${ }^{17}$ attended call while driving. This difference might be due to less availability of vehicles and the awareness of the harmful effects of the use of mobile phone during driving which is risky and my lead to accidents.

Some of the students were also using it during eating, in library which is similar to the study done in medical university in India. ${ }^{6}$ Although the proportion of using the mobile phone in class, library, driving and during eating is low as compared to their usage in their room, this is thought to be inappropriate. This usage pattern shows their dependence on mobile phones as they cannot resist the attraction of using it even at places where it is prohibited, risky, or while doing other important works such as eating or studying.

Age of the students played a factor in determining patterns of using the mobile phone. Older users preferred to make more calls per day as found in a study done in Malaysia. ${ }^{17}$

Ling in his study found that young adult men spent more time on the mobile phone compared to adolescent girls. Moreover, Juno found that female college students sent more texts and talked longer on their cell phones than their male counter parts. However, the pattern of mobile phone use among male and female students was found to be similar in this present study which is consistent with other studies. ${ }^{10,18}$ Bianchi and Phillips in their study claimed that mobile phone was a gender neutral device and both gender seemed to embrace mobile phone technology equally. ${ }^{19}$

Students from higher income families spent more time and money on their mobile phone as per a study done in Malaysia. ${ }^{16}$ However in this study family income status did not influence the student's mobile phone pattern.

Limitation of the present study is that the results are dependent on the assumption that the students gave honest responses to the questionnaire, as it was selfadministered.

\section{CONCLUSIONS}

In this study, it was observed that many students use mobile phone excessively. Messaging habit in the student was less in comparison to the calls made by them. The pattern of mobile phone among male and female students was found to be similar. This pattern of mobile phone among students may signal the evolution of mobile phone use from a habit to an addiction.

\section{Conflicts of Interest: None.}

\section{REFERENCES}

1. Tavakolizadeh J, Atarodi AR, Ahmadpour S, Pourgheisar A. The prevalence of excessive mobile phone use and its relation with Mental Health Status and Demographic Factors among the Students of Gonabad University of Medical Sciences in 2011-2012. Razavi Int J Med. 2014;2(1):15527. [Full Text]

2. Balakrishnan V, Raj RG. Exploring the relationship between urbanized Malaysian youth and their mobile phones: A quantitative approach. Telemat Inform. 2012;29(3):263-72. [Full Text]

3. Khan MM. Adverse effects of excessive mobile phone use. Int J Occup Med Environ Health. 2008;21(4):289-93. [Full Text]
4. Korpinen LH, Paakkonen RJ. Self-report of physical symptoms associated with using mobile phones and other electrical devices. Bioelectromagnetics. 2009;30(6):431-37. [PubMed]

5. Billieux J, Van der Linden M, D'Acremont M, Ceschi G, Zermatten A. Does impulsivity relate to perceived dependence on and actual use of the mobile phone? Applied Cognitive Psychology. 2007;21(4):527-537. [Full Text] 
6. Subba SH, Mandelia C, Pathak V, Reddy D, Goel A, et al.Ringxiety and the mobile phone usage pattern among the students of a medical college in South India. J Clin Diagn Res. 2013;7(2):205-9. [PubMed]

7. Gupta N, Garg S, Arora K. Pattern of mobile phone usage and its effects on psychological health, sleep, and academic performance in students of a medical university. Natl J Physiol Pharm Pharmacol. 2016; 6(2):132-139. [Full Text]

8. Sharma N, Sharma P, Sharma N, Wavare RR. Rising concern of nomophobia amongst Indian medical students. Int J Res Med Sci. 2015;3(3):705-7. [Full Text]

9. A report on study of mobile phone usage among the teenagers and youth in Mumbai. Market analysis and consumer research organization. 2004. [Full Text]

10. Yogesh S, Abha S, Priyanka S. Mobile usage and sleep patterns among medical students. Indian J Physiol Pharmacol. 2014;58(1):100-103. [ubMed]

11. Mehtaj M. The usage pattern of mobile phone among university students: A study on Dhaka City. Journal of Business Studies. 2016;37(1):99-111. [Full Text]

12. Roberts JA, Yaya LH, Manolis C. The invisible addiction: cell-phone activities and addiction among male and female college students. J Behav Addict. 2014;3(4):254-65. [PubMed]

13. Tandon A, Garg M. Mobile phone and internet adoption \& consumption patterns of college students in India. Elixir Marketing Mgmt. 2013;55:12754-12759. [Full Text]
14. North D, Johnston K, OphoffJ. The use of mobile phones by South African university students. Issues in Informing Science and Information Technology. 2014;11:115-138. [Full Text]

15. Jambulingam $\mathrm{M}$, Sorooshian S. Usage of mobile features among Undergraduates and Mobile learning. Curr Res J Soc Sci. 2013;5(4):130-3. [Full Text]

16. Zulkefly SN, Baharudin R. Mobile Phone use Amongst Students in a University in Malaysia: Its Correlates and Relationship to Psychological Health. European Journal of Scientific Research. 2009;37(2):206-18. [Full Text]

17. George S, Saif N, Joseph BB. A study on the mobile phone usage pattern and its dependence among medical students of a college in Kerala, India. Int J Res Med Sci. 2017;5(8):3615-3619. [․ull Text]

18. Mazloomy Mahmoodabad SS, Barkhordari A, Nadrian $\mathrm{H}$, Moshiri O, Yavari MT. Survey of ownership and use of mobile phones among medical science students in Yazd. Pak J Biol Sci. 2009;12(21):1430-3. [ubMed]

19. Bianchi A, Phillips JG. Psychological predictors of problem mobile phone use. Cyber Psychol Behav. 2005;8(1):39-51. [PubMed] 